\title{
Diachrony in legal terminology: a case study on the rights of victims of crime in the $\mathrm{EU}$
}

Diachronie en terminologie juridique : étude de cas sur le droit des victimes de la criminalité dans l'Union européenne

\section{Katia Peruzzo}

\section{OpenEdition}

\section{Journals}

Electronic version

URL: http://journals.openedition.org/asp/5426

DOI: $10.4000 /$ asp. 5426

ISSN: 2108-6354

\section{Publisher}

Groupe d'étude et de recherche en anglais de spécialité

\section{Printed version}

Date of publication: 1 November 2018

Number of pages: 113-134

ISSN: 1246-8185

\section{Electronic reference}

Katia Peruzzo, «Diachrony in legal terminology: a case study on the rights of victims of crime in the EU », ASp [Online], 74 | 2018, Online since 01 November 2019, connection on 01 November 2020. URL http://journals.openedition.org/asp/5426 ; DOI : https://doi.org/10.4000/asp.5426

This text was automatically generated on 1 November 2020

Tous droits réservés 


\section{Diachrony in legal terminology: a case study on the rights of victims of crime in the EU}

Diachronie en terminologie juridique : étude de cas sur le droit des victimes de la criminalité dans l'Union européenne

Katia Peruzzo

\section{Introduction}

$1 \quad$ Legal terminology has traditionally been considered "the most visible and striking linguistic feature of legal language" (Cao 2007: 53) and has generally received much scholarly attention (Bajčić 2010; Bestué 2016; Biel 2008; Ioriatti Ferrari 2014; Prieto Ramos 2014; Sandrini 1996). However, the diachronic evolution of legal terminology, which is deemed to change very slowly (Lemmens 2011), has not attracted the same degree of interest, especially with regard to variation and development in the short term.

2 This article presents a diachronic study carried out on the terminology referring to the fundamental rights of victims of crime within the European Union (EU). This terminology was extracted from EU legal acts adopted to increase the degree of harmonisation in the relevant legal field. The notion of "victim of crime" seems reasonably straightforward, and anybody would very likely agree that any victim deserves to have a role in the prosecution of the crime he or she suffered from. Likewise, nobody would deny that any victim should be protected from further negative consequences of that crime, such as secondary victimisation, intimidation, and retaliation. However, both the role of victims in criminal proceedings and victims' rights have been neglected for so long that victims have been considered the "forgotten persons" of many modern criminal justice systems (Morgan 1987). Only through the recognition of this legislative vacuum, as from the 1980s, have victims' rights received increased attention, especially at an international level (Bassiouni 2006; for a more 
detailed account on the changing role of victims in the European supranational and some national criminal justice systems, see Lupária 2015).

The need to strengthen victims' rights has not left the European legal scenario unaffected. At the time when the first steps were taken to rescue victims from oblivion, the European Community had no competences in criminal matters. It was not until the foundation of the European Union and the transfer of certain criminal powers to the EU in the 1990s that an "Area of Freedom, Security and Justice" (AFSJ) was established. The AFSJ contributed to moving the protection of victims of crime towards the top of the political priority list of the EU, because the right of European citizens to live in a safe European area implied that the EU had to provide assistance also to individuals falling victim of crime within its territory. An exhaustive review of the EU legislation regulating the rights and the role of victims in criminal proceedings goes beyond the scope of this article, but a brief overview of the two legal acts that constitute the corpus used in this study is considered necessary to provide the minimum background information to understand their relevance to the main topic.

\section{Victims of crime in EU legislation: a brief overview}

4 The corpus for the study presented in this article consists of two EU legal acts, the first of which is Council Framework Decision 2001/220/JHA. This unprecedented Framework Decision is the first supranational hard-law act specifically dealing with the standing of victims in criminal proceedings (Groenhuijsen \& Pemberton 2009). It constitutes a historical turning point in the development of victims' rights not only within the EU, but also from a global international perspective. According to its preamble, there was a compelling need at the beginning of the new millennium for rules and practices concerning the standing of victims and their rights to be approximated, in particular as regards the right to be treated with respect for their dignity, the right to provide and receive information, the right to understand and be understood, the right to be protected at the various stages of procedure, and the right to have allowance made for the disadvantage of living in a different Member State from the one in which the crime was committed. Despite the indelible mark left by this measure, its concrete effects were not as satisfactory as expected, especially because no remedy was available in case the Member States did not implement the Framework Decisions correctly.

Some years later, Directive 2004/80/EC was adopted. This act allowed certain categories of cross-border victims, i.e. victims of crimes committed in a Member State other than that of their residence, to access an EU-funded compensation scheme. The possibility of adopting directives rather than framework decisions led to much more satisfactory and effective results, also because the European Commission was granted the power to start infringement procedures against Member States failing to implement directives within the prescribed time limit. EU institutions started considering the development of a legal framework capable of offering victims a wide range of entitlements and protection measures. As a result, a series of directives was adopted to harmonise Member States' criminal law and introduce certain victim-oriented provisions, i.e. Directives 2011/36/EU, 2011/93/EU, and 2017/541/EU. However, these directives only address specific types of offences, namely trafficking in human beings, sexual abuse and sexual exploitation of children, child pornography, and terrorism, and do not provide for generally applicable victims' rights. 
6 The most general provisions adopted by the EU in relation to victims of crime are contained in another legal act, i.e. Directive 2012/29/EU, which replaced Council Framework Decision 2001/220/JHA and is the second text included in the corpus. From a legal perspective, Directive 2012/29/EU is the most articulated legal instrument adopted in this field, providing advanced minimum standards on the rights, support and protection of victims of crime. The analysis of its single provisions and the study of its impact on national legislations are prerogatives of legal scholars (Lupária \& Della Torre, forthcoming), so no further discussion is provided here. What the study presented in this article is concerned with is rather the potential evolution of the terminology used in this field. In order to verify whether the terminology related to victims of crime and their rights underwent any changes in the 2001-2012 period, a diachronic analysis of the terms starting with the head element "right" in both Framework Decision 2001/220/JHA and this Directive was carried out, as illustrated in the sections below.

\section{Victims' "rights" from a linguistic perspective: theoretical framework}

7 Council Framework Decision 2001/220/JHA and Directive 2012/29/EU are the two main EU legal acts dealing with the protection and rights of all types of victims of crime, regardless of the type of crime they were subject to and the place where the crime was committed. The Directive was adopted to go beyond the safeguards provided for in the Framework Decision it replaced and lay the basis for a more structured and efficient legal framework. This replacement did not correspond to a mere change in the type of legal instrument used: it involved the development, further consideration, and a more detailed indication of the rights that Member States shall grant to victims of crime.

8 The hypothesis underlying this study was that the legal development of the field over the decade between the two acts could have influenced the language used to refer to the rights enshrined in the acts themselves. In other words, the hypothesis was that the terminology of the legal field under examination experienced what Picton (2011) terms "short-period diachronic phenomena."

9 Picton (2011: 142; 2014: 168) proposed a typology of terminology dynamics in shortterm diachrony based on the analysis of two short-period diachronic corpora related to space technology. According to Picton, evolution phenomena can be classified into four main categories. The first is labelled "novelty and obsolescence" and is the most articulated and extensively developed category in her typology, given that it is subdivided into eleven subcategories. Four subcategories correspond to types of neology (complete, formal, semantic, and relative, with formal neology further subdivided into controlled and free formal neology), four subcategories to types of necrology (complete, formal, semantic, and relative, with formal necrology further subdivided into controlled and free formal necrology), two refer to the appearance and disappearance of a referent, and one consists in the migration of terms and concepts with domains being described as "permeable" (Picton 2011: 146). Since some of the types of neology described by Picton appear in the corpus analysed in this study, their definitions are recalled here for the sake of clarity. In Picton's words (2011: 143-144), complete neology is "the simultaneous appearance of a new concept and a new denomination associated to it in a domain," formal neology occurs "when a new 
denomination appears for an existing concept," and semantic neology occurs "when an existing denomination is used to convey a new meaning." As regards relative neology, Picton does not provide a definition, but illustrates the phenomenon through an example and by adopting De Bessé's distinction (2000: 184) between knowledge domain ("domaine de connaissance") and domain of activity ("domaine d'activité"). A relative neologism is thus a term that is already used and known within a knowledge domain but constitutes a novelty within a certain domain of activity which belongs to that knowledge domain. The second main category identified by Picton (2011: 146) is "implantation of terms/concepts," where implantation is defined as "the step when a denomination is finally adopted and integrated in a terminology." The third category is termed "centrality" in Picton's first typology proposal (2011: 146) and "focus" in Picton's later work (2014: 173); it deals with the relevance of a certain topic within a domain in a specific period of time and the use of terms to convey a change or shift in the domain. The last category is called "modifications of specifications and settings of specialised documents" and refers to "the evolution of the nature and settings of specialised documents" (Picton 2011: 147). The phenomena in this category do not necessarily imply the evolution of terms or concepts but are considered useful for understanding how specialised domains and the relevant technical writing evolve.

By taking a closer look at Picton's typology, it can be said that only the first two categories deal specifically with the evolution of single terms and concepts, while the third category focuses on topics, and the fourth on specialised documents. Given the purpose of this study, only the first two categories are taken into consideration here.

\section{Victims' "rights" from a linguistic perspective: methodology}

11 As mentioned above, the aim of this study was to verify whether, in a short period of eleven years, changes related to the designations of different types of victims' rights could be detected. Therefore, Council Framework Decision 2001/220/JHA and Directive 2012/29/EU were used as a corpus. This type of supranational legislation is published in all the official languages of the EU; however, for the purposes of this study only the English versions of the two legal acts were considered, the details of which are presented in Table 1 below. At this point, a brief digression in the nature and development of legal acts is in order. In fact, when specialised texts from other domains are considered, they are usually analysed in their final version, unless the study requires otherwise. This is also because the final version is usually the only version available. As regards legally binding texts, such as not only the acts under examination in this article but also acts passed by national legislative bodies, it is usual and even mandatory to have the drafts published. This means that it is possible to compare the draft legislation with the actual final version of the act, as done in Section 4 below.

Table 1: Corpus details

\begin{tabular}{|l|l|l|}
\hline Document & Publication date & No. of tokens \\
\hline Council Framework Decision 2001/220/JHA & $15 / 03 / 2001$ & 2,989 \\
\hline
\end{tabular}




\begin{tabular}{|l|l|l|}
\hline Directive 2012/29/EU & $25 / 10 / 2012$ & 13,671 \\
\hline
\end{tabular}

Given that victims' rights constitute the central idea of the protection and assistance of victims, the lemma "right" was used as a keyword in context (KWIC) in the Concordance function available in the corpus-analysis tool Sketch Engine. The number of occurrences in the corpus is given in Table 2 .

Table 2: Number of occurrences of the lemma "right" in the corpus

\begin{tabular}{|l|l|}
\hline Document & No. of occurrences of lemma "right" \\
\hline Council Framework Decision 2001/220/JHA & 12 \\
\hline Directive 2012/29/EU & 92 \\
\hline
\end{tabular}

13 As can be seen from Tables 1 and 2, the second legal act is much longer than the first one and contains a higher number of occurrences of the lemma "right". The full list of concordances containing the KWIC "right" extracted from the corpus was filtered so as to obtain a list of expressions referring to types of rights afforded to victims of crime and following the pattern "right + TYPE OF RIGHT". Therefore, all the expressions referring to either victims' rights in general, such as "rights of victims of crime" or "rights set out in this Directive," or rights granted to other individuals or parties, such as "rights of the offender," were discarded. The so-obtained expressions are provided for the two acts separately in Tables 3 and 4. Although some of these may seem particularly long (see, for instance, "right to have allowance made for the disadvantage of living in a different Member State from the one in which the crime was committed" in Table 3), all the expressions extracted that followed the specified pattern were considered terms or terminological units, given that they refer to broad but definite legal concepts. By applying these criteria, 43 terms were extracted for a total of 46 occurrences.

Table 3: Terms following the pattern "right + TYPE OF RIGHT" extracted from Framework Decision 2001/220/JHA

\begin{tabular}{|c|c|c|c|c|c|c|c|}
\hline \multicolumn{4}{|l|}{ Recitals } & \multicolumn{4}{|l|}{ Articles } \\
\hline Term & $\begin{array}{l}\text { Text } \\
\text { section }\end{array}$ & $\begin{array}{l}\text { Type of } \\
\text { text }\end{array}$ & $\begin{array}{l}\text { No. } \\
\text { of } \\
\text { occ. }\end{array}$ & Term & $\begin{array}{l}\text { Text } \\
\text { section }\end{array}$ & $\begin{array}{l}\text { Type of } \\
\text { text }\end{array}$ & $\begin{array}{l}\text { No. } \\
\text { of } \\
\text { occ. }\end{array}$ \\
\hline $\begin{array}{l}\text { right to compensation for } \\
\text { damages, including legal } \\
\text { costs }\end{array}$ & $\begin{array}{l}\text { Recital } \\
(3)\end{array}$ & $\begin{array}{l}\text { running } \\
\text { text }\end{array}$ & 1 & $\begin{array}{ll}\text { Right } & \text { to } \\
\text { compensation } & \text { in } \\
\text { the course } & \text { of } \\
\text { criminal } & \\
\text { proceedings } & \end{array}$ & $\begin{array}{l}\text { Article } \\
9\end{array}$ & heading & 1 \\
\hline
\end{tabular}




\begin{tabular}{|c|c|c|c|c|c|c|c|}
\hline $\begin{array}{l}\text { right to be treated with } \\
\text { respect for their [victims'] } \\
\text { dignity }\end{array}$ & $\begin{array}{l}\text { Recital } \\
(8)\end{array}$ & $\begin{array}{l}\text { running } \\
\text { text }\end{array}$ & 1 & & & & \\
\hline $\begin{array}{l}\text { right to provide and receive } \\
\text { information }\end{array}$ & $\begin{array}{l}\text { Recital } \\
(8)\end{array}$ & $\begin{array}{l}\text { running } \\
\text { text }\end{array}$ & 1 & $\begin{array}{l}\text { Right to receive } \\
\text { information }\end{array}$ & $\begin{array}{l}\text { Article } \\
4\end{array}$ & heading & 1 \\
\hline $\begin{array}{l}\text { right to understand and be } \\
\text { understood }\end{array}$ & $\begin{array}{l}\text { Recital } \\
(8)\end{array}$ & $\begin{array}{l}\text { running } \\
\text { text }\end{array}$ & 1 & & & & \\
\hline $\begin{array}{l}\text { right to be protected at the } \\
\text { various stages of procedure }\end{array}$ & $\begin{array}{l}\text { Recital } \\
(8)\end{array}$ & $\begin{array}{l}\text { running } \\
\text { text }\end{array}$ & 1 & $\begin{array}{ll}\text { Right } & \text { to } \\
\text { protection }\end{array}$ & $\begin{array}{l}\text { Article } \\
8\end{array}$ & heading & 1 \\
\hline $\begin{array}{l}\text { right to have allowance } \\
\text { made for the disadvantage } \\
\text { of living in a different } \\
\text { Member State from the one } \\
\text { in which the crime was } \\
\text { committed }\end{array}$ & $\begin{array}{l}\text { Recital } \\
(8)\end{array}$ & $\begin{array}{l}\text { running } \\
\text { text }\end{array}$ & 1 & & & & \\
\hline
\end{tabular}

Table 4: Terms following the pattern "right + TYPE OF RIGHT" extracted from Directive 2012/29/EU

\begin{tabular}{|c|c|c|c|c|c|c|c|}
\hline \multicolumn{4}{|l|}{ Recitals } & \multicolumn{4}{|l|}{ Articles } \\
\hline Term & $\begin{array}{l}\text { Text } \\
\text { section }\end{array}$ & $\begin{array}{l}\text { Type of } \\
\text { text }\end{array}$ & $\begin{array}{l}\text { No. } \\
\text { of } \\
\text { occ. }\end{array}$ & Term & $\begin{array}{l}\text { Text } \\
\text { section }\end{array}$ & $\begin{array}{l}\text { Type of } \\
\text { text }\end{array}$ & $\begin{array}{l}\text { No. } \\
\text { of } \\
\text { occ. }\end{array}$ \\
\hline \multirow[t]{2}{*}{$\begin{array}{l}\text { right to information, } \\
\text { interpretation and } \\
\text { translation }\end{array}$} & $\begin{array}{l}\text { Recital } \\
(30)\end{array}$ & $\begin{array}{l}\text { running } \\
\text { text }\end{array}$ & 1 & $\begin{array}{l}\text { Right to understand } \\
\text { and to be understood }\end{array}$ & $\begin{array}{l}\text { Article } \\
3\end{array}$ & heading & 1 \\
\hline & & & & $\begin{array}{l}\text { Right to receive } \\
\text { information from the } \\
\text { first contact with a } \\
\text { competent authority }\end{array}$ & $\begin{array}{l}\text { Article } \\
4\end{array}$ & heading & 1 \\
\hline $\begin{array}{l}\text { right to information } \\
\text { about the time and } \\
\text { place of a trial }\end{array}$ & $\begin{array}{l}\text { Recital } \\
(31)\end{array}$ & $\begin{array}{l}\text { running } \\
\text { text }\end{array}$ & 1 & $\begin{array}{lr}\text { Right to } & \text { receive } \\
\text { information } & \text { about } \\
\text { their case } & \end{array}$ & $\begin{array}{l}\text { Article } \\
6\end{array}$ & heading & 1 \\
\hline \multirow[t]{2}{*}{$\begin{array}{l}\text { right to } \\
\text { appeal of a decision } \\
\text { to release the } \\
\text { offender }\end{array}$} & $\begin{array}{l}\text { Recital } \\
(33)\end{array}$ & $\begin{array}{l}\text { running } \\
\text { text }\end{array}$ & 1 & & & & \\
\hline & & & & $\begin{array}{l}\text { Right to interpretation } \\
\text { and translation }\end{array}$ & $\begin{array}{l}\text { Article } \\
7\end{array}$ & heading & 1 \\
\hline
\end{tabular}




\begin{tabular}{|c|c|c|c|c|c|c|c|}
\hline $\begin{array}{l}\text { right to challenge a } \\
\text { decision } \\
\text { finding that there is } \\
\text { no need for } \\
\text { interpretation or } \\
\text { translation }\end{array}$ & $\begin{array}{l}\text { Recital } \\
(35)\end{array}$ & $\begin{array}{l}\text { running } \\
\text { text }\end{array}$ & 1 & & & & \\
\hline $\begin{array}{l}\text { right to a review of a } \\
\text { decision not to } \\
\text { prosecute }\end{array}$ & $\begin{array}{l}\text { Recital } \\
(43)\end{array}$ & $\begin{array}{l}\text { running } \\
\text { text }\end{array}$ & 2 & $\begin{array}{l}\text { Rights in the event of a } \\
\text { decision not to } \\
\text { prosecute }\end{array}$ & $\begin{array}{l}\text { Article } \\
11\end{array}$ & heading & \begin{tabular}{|llll}
1 & & & \\
\end{tabular} \\
\hline & & & & $\begin{array}{l}\text { right to a review of a } \\
\text { decision not to } \\
\text { prosecute }\end{array}$ & $\begin{array}{l}\text { Article } \\
11\end{array}$ & $\begin{array}{l}\text { running } \\
\text { text }\end{array}$ & 2 \\
\hline & & & & $\begin{array}{l}\text { Rights of victims } \\
\text { resident in another } \\
\text { Member State }\end{array}$ & $\begin{array}{l}\text { Article } \\
17\end{array}$ & heading & \begin{tabular}{|llll}
1 & & & \\
\end{tabular} \\
\hline $\begin{array}{l}\text { right to a review of a } \\
\text { decision of the } \\
\text { prosecutor not to } \\
\text { prosecute }\end{array}$ & $\begin{array}{l}\text { Recital } \\
(45)\end{array}$ & $\begin{array}{l}\text { running } \\
\text { text }\end{array}$ & 1 & & & & \\
\hline $\begin{array}{ll}\text { right } & \text { to } \\
\text { reimbursement } & \\
\text { of expenses in } \\
\text { criminal } \\
\text { proceedings }\end{array}$ & $\begin{array}{l}\text { Recital } \\
(47)\end{array}$ & $\begin{array}{l}\text { running } \\
\text { text }\end{array}$ & 1 & $\mid \begin{array}{ll}\text { Right } & \text { to } \\
\text { reimbursement } & \text { of } \\
\text { expenses } & \end{array}$ & $\begin{array}{l}\text { Article } \\
14\end{array}$ & heading & 1 \\
\hline $\begin{array}{l}\text { right to have } \\
\text { property returned }\end{array}$ & $\begin{array}{l}\text { Recital } \\
(48)\end{array}$ & $\begin{array}{l}\text { running } \\
\text { text }\end{array}$ & 1 & $\begin{array}{l}\text { Right to the return of } \\
\text { property }\end{array}$ & $\begin{array}{l}\text { Article } \\
15\end{array}$ & heading & 1 \\
\hline right to property & $\begin{array}{l}\text { Recital } \\
(66)\end{array}$ & $\begin{array}{l}\text { running } \\
\text { text }\end{array}$ & 1 & & & & \\
\hline $\begin{array}{l}\text { right to a decision } \\
\text { on compensation } \\
\text { from the offender }\end{array}$ & $\begin{array}{l}\text { Recital } \\
(49)\end{array}$ & $\begin{array}{l}\text { running } \\
\text { text }\end{array}$ & 1 & $\begin{array}{l}\text { Right to decision on } \\
\text { compensation from } \\
\text { the offender in } \\
\text { the course of criminal } \\
\text { proceedings }\end{array}$ & $\begin{array}{l}\text { Article } \\
16\end{array}$ & heading & 1 \\
\hline right to a fair trial & $\begin{array}{l}\text { Recitals } \\
(54) \text { and } \\
(66)\end{array}$ & $\begin{array}{l}\text { running } \\
\text { text }\end{array}$ & 2 & Right to be heard & $\begin{array}{l}\text { Article } \\
10\end{array}$ & heading & 1 \\
\hline $\begin{array}{l}\text { right to dignity, life, } \\
\text { physical and mental } \\
\text { integrity, liberty and } \\
\text { security }\end{array}$ & $\begin{array}{l}\text { Recital } \\
(66)\end{array}$ & $\begin{array}{l}\text { running } \\
\text { text }\end{array}$ & 1 & Right to protection & $\begin{array}{l}\text { Article } \\
18\end{array}$ & heading & 1 \\
\hline
\end{tabular}




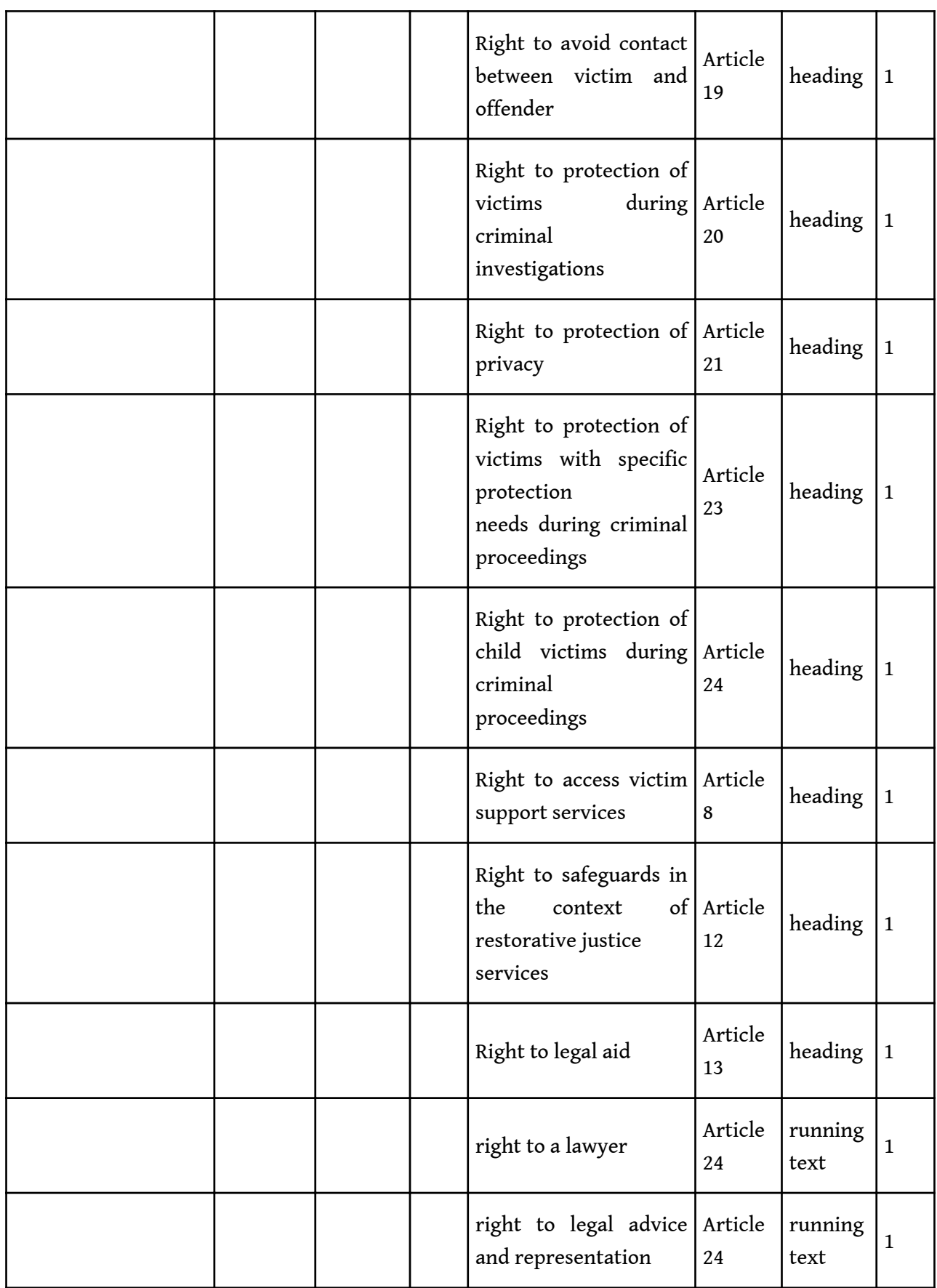

\section{Victims' "rights" in a short-period diachronic perspective}

What emerges from Table 3 is that, in the 2001 Framework Decision, the frequency of terms following the pattern "right + TYPE OF RIGHT" is higher in the Recitals than in the Articles section. Furthermore, in the latter section these terms only occur in headings, which means that, in the running text of the Articles, other linguistic means are used to provide for victims' rights that do not require the use of terms starting with "right." This is the case, for instance, of the following Articles (emphasis added): 
Article 4

Right to receive information

1. Each Member State shall ensure that victims in particular have access, as from their first contact with law enforcement agencies, by any means it deems appropriate and as far as possible in languages commonly understood, to information of relevance for the protection of their interests. [...]

Article 8

\section{Right to protection}

1. Each Member State shall ensure a suitable level of protection for victims and, where appropriate, their families or persons in a similar position, particularly as regards their safety and protection of their privacy, where the competent authorities consider that there is a serious risk of reprisals or firm evidence of serious intent to intrude upon their privacy.

Article 9

Right to compensation in the course of criminal proceedings

1. Each Member State shall ensure that victims of criminal acts are entitled to obtain a decision within reasonable time limits on compensation by the offender in the course of criminal proceedings, except where, in certain cases, national law provides for compensation to be awarded in another manner.

A closer look at the relationship between the terms used in the heading and the way the right is expressed in the running text of the relevant Article reveals that the role of the former is to encapsulate what is expressed in more detail in the latter. However, by examining the content of other Articles in the 2001 Framework Decision whose headings do not contain the word "right," it is easy to notice that the number of rights goes beyond the number of headings starting with "right." To clarify what is meant here two examples are provided below (emphasis added):

Article 3

Hearings, and provision of evidence

Each Member State shall safeguard the possibility for victims to be heard during proceedings and to supply evidence. [...]

Article 7

Victims' expenses with respect to criminal proceedings

Each Member State shall, according to the applicable national provisions, afford victims who have the status of parties or witnesses the possibility of reimbursement of expenses incurred as a result of their legitimate participation in criminal proceedings.

16 As can be seen from the examples provided, the EU legislator chose to grant victims, among others, the right to be heard, the right to provide evidence and the right to reimbursement of expenses, but these rights are not referred to by using a term explicitly designating the rights as in the case of Articles 4, 8 and 9. This means that, from a linguistic perspective, the rights in the Framework Decision can be divided into two categories. The first category includes the rights that are identified by a term following the pattern "right + TYPE OF RIGHT," while the second comprises the rights that are expressed in the form of an obligation for Member States. In most cases, the second category follows the pattern "Member States shall ensure/safeguard/afford + victims + TYPE OF RIGHT." The recognition of these two categories provides evidence that "denominations and concepts evolve separately" (Picton 2011: 143), and that the implementation of new concepts in a certain EU legal field is not necessarily accompanied by a simultaneous creation of new terminology.

In the 2012 Directive, as in the 2001 Framework Decision, the terms following the pattern "right + TYPE OF RIGHT" can be found in both the Recitals and the Articles 
sections. Furthermore, in both the Framework Decision and the Directive all the terms found in the Recitals ( 6 and 14 occurrences respectively) occur in the running text. However, while in the former legal act all the terms in the Articles (3 occurrences) correspond to a heading, in the latter legal act 19 out of 23 occurrences correspond to a heading and the remaining four appear in the running text. By focusing only on the terms serving as headings, it could be concluded that the victims' rights provided for in the 2012 Directive seem more detailed and advanced than those envisaged by the 2001 Framework Decision. For instance, the 2001 Framework Decision provides for a generic right to protection (Article 8), while the 2012 Directive includes five Articles devoted to the same right, four of which address subtypes (i.e. right to protection of victims during criminal investigations, right to protection of privacy, right to protection of victims with specific protection needs during criminal proceedings, and right to protection of child victims during criminal proceedings). However, the fact that a higher number of headings with the pattern "right + TYPE OF RIGHT" was extracted in the 2012 Directive than in the 2001 Framework Decision does not mean that the underlying right was not already contemplated in 2001. By way of example, the right to avoid contact between victim and offender set forth in Article 19 can be traced also in the Framework Decision, where it is subsumed in the right to protection, as shown below:

Article 8

Right to protection

[...]

3. Each Member State shall further ensure that contact between victims and

offenders within court premises may be avoided, unless criminal proceedings require such contact.

Therefore, although no term identifies the right provided for in this example, it can still be affirmed that this right was already present - in its embryonic form - in the Framework Decision and that it was further developed in the Directive. Indeed, the only rights that constitute a real novelty in the Directive are the rights in the event of a decision not to prosecute and the right to a lawyer for child victims, no trace of which could be found in the Framework Decision.

In order to observe instances of short-period diachronic phenomena, the data provided in Tables 3 and 4 need to be compared. Before doing so, since the draft version of legally binding texts are generally available (see Section 3), we first considered it necessary to compare the draft and final versions of the 2001 Framework Decision to identify possible signs of terminological evolution. What emerged from this comparison is that eight out of nine terms following the pattern "right + TYPE OF RIGHT" reported in Table 3 were already present in the draft version. Therefore, in the draft version of the act, these eight terms fall within the subcategory of complete neology (Picton 2011: 143). This phenomenon can also be described as "primary term formation" (Sager 1990: 80), which "occurs as part of the development of new ideas in all domains," and examples of which "can be found in all scientific and societal fields" (Temmerman 2018: 9-10). However, it must be borne in mind that primary term formation can be either mono- or multi-lingual (Fischer 2010: 26) and that, within the $\mathrm{EU}$, terminology is created by means of a two-step process, which involves first a multilingual primary term creation for the "dominant languages," followed by the secondary creation of terms via translation into most other languages (Fischer 2010: 28-29). Given the role of English within the EU, it can be said that the complete neologisms in the draft Framework Decision are the result of primary term creation. 
The eight complete neologisms mentioned above underwent no modification in the passage from the draft to the final version. The same cannot be said of the heading of Article 9. Indeed, the term used in the draft version is "right to compensation under criminal procedure," which constituted a complete neology in the draft version but was changed into "right to compensation in the course of criminal proceedings" in the final version of the Framework Decision. The legislative procedure thus led to an instance of formal neology (Picton 2011: 143), since the concept remained unchanged, and a new denomination, although derived from the previous one, appeared in the final version of the act. Formal neology thus falls within denominative variation, namely "the phenomenon in which one and the same concept has different denominations, [...] i.e. lexicalised forms, with a minimum of stability and consensus among the users of units in a specialised domain" (Freixa 2006: 51). This case is useful to anticipate one of the types of evolution that can be observed when comparing the Framework Decision with the Directive. Indeed, this instance of formal neology involved changes to the original term that can be considered minor, and the examples which are discussed below follow the same trend.

By comparing the terms extracted from the Framework Decision with those extracted from the Directive, three phenomena related to short-period evolution can be observed, namely complete neology, formal neology, and stability. The latter phenomenon consists in "the consistent usage of terms in the short-period diachronic corpus analysed" (Peruzzo 2013: 42). Stability is not mentioned in Picton's typology, but it can be subsumed under the category of implantation of terms/concepts, given that the consistent use of a term over time suggests the adoption and integration of the term into the terminology of a field or domain. These three phenomena are illustrated through the examples provided in Table 5.

Table 5: Examples of short-period evolution phenomena in two EU victim-related acts

\begin{tabular}{|l|l|l|l|l|}
\hline $\begin{array}{l}\text { Council } \\
\text { Decision } \\
2001 / 220 / \mathrm{JHA}\end{array}$ & $\begin{array}{l}\text { Directive } \\
2012 / 29 / \mathrm{EU}\end{array}$ & Recitals & Articles & $\begin{array}{l}\text { Short-period } \\
\text { evolution } \\
\text { phenomenon }\end{array}$ \\
\hline Recitals & Articles & $\begin{array}{l}\text { right to a review } \\
\text { of a decision not } \\
\text { to prosecute }\end{array}$ & $\begin{array}{l}\text { Rights in the event } \\
\text { of a decision not to } \\
\text { prosecute }\end{array}$ & $\begin{array}{l}\text { complete } \\
\text { neology }\end{array}$ \\
\hline & & $\begin{array}{l}\text { prosecutor not to } \\
\text { prosecute }\end{array}$ & $\begin{array}{l}\text { right to a review of } \\
\text { a decision not to } \\
\text { prosecute } \\
\text { recision of the } \\
\text { promplete } \\
\text { neology }\end{array}$ \\
\hline & & $\begin{array}{l}\text { complete } \\
\text { neology }\end{array}$ \\
\hline
\end{tabular}




\begin{tabular}{|c|c|c|c|c|}
\hline $\begin{array}{lr}\text { right } & \text { to } \\
\text { compensation for } \\
\text { damages, } \\
\text { including r legal } \\
\text { costs }\end{array}$ & $\begin{array}{l}\text { Right to } \\
\text { compensation in the } \\
\text { course of criminal } \\
\text { proceedings }\end{array}$ & $\begin{array}{l}\text { right to a } \\
\text { decision } \\
\text { compensation } \\
\text { from the offender }\end{array}$ & $\begin{array}{l}\text { Right to decision on } \\
\text { compensation from } \\
\text { the offender in } \\
\text { the course of } \\
\text { criminal } \\
\text { proceedings }\end{array}$ & $\begin{array}{l}\text { formal neology } \\
-\quad 1 \text { st } \\
\text { subcategory }\end{array}$ \\
\hline & $\begin{array}{l}\text { the possibility for } \\
\text { victims to be heard } \\
\text { during proceedings } \\
\text { and to supply } \\
\text { evidence }\end{array}$ & & Right to be heard & $\begin{array}{l}\text { formal neology } \\
-\quad 2 n d \\
\text { subcategory }\end{array}$ \\
\hline $\begin{array}{l}\text { right to provide } \\
\text { and receive } \\
\text { information }\end{array}$ & $\begin{array}{l}\text { Right to receive } \\
\text { information }\end{array}$ & & $\begin{array}{l}\text { Right to receive } \\
\text { information from } \\
\text { the first contact } \\
\text { with a competent } \\
\text { authority } \\
\text { Right to receive } \\
\text { information about } \\
\text { their case }\end{array}$ & $\begin{array}{l}\text { formal neology } \\
-\quad 3 \mathrm{rd} \\
\text { subcategory }\end{array}$ \\
\hline $\begin{array}{l}\text { right to be } \\
\text { protected at the } \\
\text { various stages of } \\
\text { procedure }\end{array}$ & Right to protection & & Right to protection & stability \\
\hline
\end{tabular}

The first phenomenon related to short-period evolution is complete neology. As mentioned above, most of the rights granted to victims of crime by the Directive were already enshrined in the Framework Decision, although the linguistic expressions used to refer to them did not always correspond to a term. The only exceptions are the rights in the event of a decision not to prosecute, and the right to a lawyer for child victims. Interestingly, the first entitlement is expressed by means of the plural form "rights," although all five paragraphs constituting the Article can be said to refer to a single right, i.e. the right to a review of a decision not to prosecute. The reason for choosing a plural form in the heading lies in the fact that this right can be exercised in different ways through procedural rules that are determined by the Member States' national law, and that these ways also depend on the circumstances of the single case. On the other hand, it is relevant to notice that the Directive entitles child victims to a lawyer, a right provided for in Article 24 ("Right to protection of child victims during criminal proceedings"). Under this right, in case of a conflict of interest between a child victim and the holders of parental responsibility during criminal proceedings, the victim has the right to legal advice and representation in his or her own name, a novelty compared to the 2001 Framework Decision.

The second phenomenon related to short-period evolution is formal neology. In her typology, Picton (2011: 143-144) distinguishes two types of formal neology, i.e. "controlled formal neology" and "free formal neology." The former type results from an intervention by a normalisation body, while in the latter no such intervention is involved. In the specific case of EU legal acts, especially when drafted in one of the 
"dominant languages," no normalisation bodies in the sense envisaged by Picton are involved in the drafting process. However, it can be stated that the EU legislator's intentions and the drafting constraints have a role in the linguistic planning of EU legislative texts. Leaving Picton's subcategories aside, different instances of formal neology were identified in the two texts, on whose basis an alternative classification is proposed which consists of three subcategories.

The first subcategory of formal neology occurs when one term appears for an already existing concept that is referred to by a term. In Table 3, this phenomenon is illustrated through the example related to compensation. By looking at the terms used in the Article headings, it could be argued that the right envisaged in the Directive is more specific than the one provided for in the Framework Decision, given that the term extracted from the Directive contains two "new" elements, i.e. a "decision" and "from the offender." However, the examination of the body of Article 9(1) reveals that both elements were already present in the earlier EU act, regardless of the heading given to the Article (emphasis added):

Article 9

Right to compensation in the course of criminal proceedings

Each Member State shall ensure that victims of criminal acts are entitled to obtain a decision within reasonable time limits on compensation by the offender in the course of criminal proceedings, except where, in certain cases, national law provides for compensation to be awarded in another manner.

On the other hand, conceptual differences play an important role in the second subcategory of formal neology detected. This category consists in the introduction of a new term to refer to an already existing concept that was not designated by a term, but rather by other linguistic means. This is the case, for instance, of Article 3 in the Directive, whose heading reads, "Right to be heard". This right is not new in the EU legal framework, since it was already enshrined in Article 3 of the 2001 Framework Decision (emphasis added):

Article 3

Hearings, and provision of evidence

Each Member State shall safeguard the possibility for victims to be heard during proceedings and to supply evidence.

$[\ldots]$

However, the inclusion of a term to designate a right can point at what Picton (2011: 140) describes as "implantation." From a conceptual point of view, this is a fundamental step, since it makes it possible to encapsulate a full legal provision and thus to condensate knowledge in a single term.

The conceptual element plays an even more significant role in the third subcategory of formal neology identified. In this case, a variable number of terms is introduced to substitute an existing term. The reason for this substitution lies in the shift from a more general term, and therefore a more general concept, to a series of hyponyms, all of which can be subsumed under the more general concept. Again, an example is provided in Table 5 to illustrate this phenomenon. In the 2001 Framework Decision, the term "Right to receive information" is used as the heading of Article 4. On the contrary, in the 2012 Directive we find two separate Articles, which are entitled "Right to receive information from the first contact with a competent authority" and "Right to receive information about their case" respectively. As in the previous case, these two rights 
were already present in the Framework Decision, but they were not referred to by using a term (emphasis added):

Article 4

Right to receive information

1. Each Member State shall ensure that victims in particular have access, as from their first contact with law enforcement agencies, by any means it deems appropriate and as far as possible in languages commonly understood, to information of relevance for the protection of their interests. [...]

2. Each Member State shall ensure that victims who have expressed a wish to this effect are kept informed of:

(a) the outcome of their complaint;

(b) relevant factors enabling them, in the event of prosecution, to know the conduct of the criminal proceedings regarding the person prosecuted for offences concerning them, except in exceptional cases where the proper handling of the case may be adversely affected;

(c) the court's sentence.

[...]

Interestingly, this change has two consequences. Firstly, from a terminological perspective, the introduction of two separate Articles has led to the disappearance of the hypernym "right to receive information" and the formal neology of two new terms. Secondly, from a conceptual perspective, this type of formal neology can be said to correspond to the affirmation of two conceptually narrower and more detailed rights to be implemented at the national level.

Finally, the third phenomenon consists in stability, i.e. the consistent use of the same "right + TYPE OF RIGHT" term in both acts. The example reported in Table 5 above, i.e. "right to protection," is the only instance characterised by stability extracted from the legal acts under examination. Its consistent use can be considered as a clue to the centrality of the concept designated by the term itself: ever since the beginning of the discussion of victims' rights within the $\mathrm{EU}$, the protection of victims has been considered a central, unmistakable entitlement.

\section{Short-period diachronic evolution from a didactic perspective}

Although the study presented in this article deals with a very specific legal topic, its results provide insights that may prove useful in different training settings. In particular, it is believed that the students who may benefit most from being exposed to problems related to diachrony in legal terminology are actually those who work with legal language on a daily basis, namely students who read law, legal translation, and legal terminology. Indeed, the examples of diachronic terminological evolution illustrated in this article were observed in a time span of merely one decade and by taking into consideration only one legal system (EU) expressed in only one language (English). This means that the evolution phenomena observed fall within "intrasystemic terminological variation" (Peruzzo 2017: 295), i.e. the variation of the terminology related to a legal field within one legal system only. However, the EU legal system is expressed in a total of twenty-four official languages and has consequences both legal and linguistic - for the national legal systems of the Member States. When the terminologies belonging to two or more legal systems expressed in the same language are compared, such as the terminologies of the EU and the UK, then instances 
of "inter-systemic terminological variation" (Peruzzo 2017: 301) may be observed. An example of this type of variation is represented by the concept of mediation in criminal cases, which is referred to as "mediation in criminal cases" in both the EU and the UK legal systems, but also by means of system-specific synonyms or variants, such as "penal mediation in the course of criminal proceedings" in the EU and "VOM," standing for "Victim-Offender Mediation", in the UK (for more examples, see MuLex, the multilingual legal terminological knowledge base available at mulex.altervista.org).

Furthermore, nowadays international, supranational and national legal systems are increasingly intertwined, which leads to a growing interaction between them. This means that both legal concepts and legal terminologies may migrate from one legal system to another. This is the case, for instance, of "restorative justice," which was originally developed in some common law countries. In the late 1990s, the term and the underlying concept were imported into the EU legal system and, since then, the implementation of this form of justice has been fostered in all EU Member States. As a consequence, restorative justice has entered national legal systems in many cases through translation or secondary term creation. In the Italian version of both legally binding and non-binding EU documents, for instance, this concept has been designated by different terms in different years, such as "giustizia riparatoria" (2002-2004), "giustizia risarcitoria" (2004), "giustizia riparatrice" and "giustizia restaurativa" (2006), as well as " giustizia riparativa" (2011 to date). The latter term is the one that is currently used in Italian national legal acts.

The fact that legal terminologies also evolve over relatively short periods of time and that the interaction between legal systems may influence the way in which this evolution occurs deserves attention in the learning environment. These aspects significantly contribute to the multidimensionality that characterises both the European legal scene and the language used in it. Understanding this multidimensionality is fundamental to come to grips with the complex relationship between the law and legal language in a multilayered legal system.

Lawyers-to-be are generally more interested in legal issues than in linguistic issues, whereas the opposite is true for legal translation and legal terminology students. Yet, trying to separate the law from the language used to express it would mean fighting a losing battle. One of the best ways to understand today's legal systems and the languages used to express them is to investigate how they are linked to each other and how they have evolved over time. As has been shown above, legal language does not always evolve in tandem with the underlying legal system, but legal language in general and legal terminology in particular give hints as to the centrality of a legal concept within a certain domain. Therefore, raising the students' awareness of the terminologisation process by exposing them to different legal acts on the same topic published in different years and under different legal systems may have various positive effects. Both law students and legal translation and terminology students would develop a higher linguistic sensitivity, with the resulting capacity to avoid potential pitfalls, such as the use of an obsolete term in an inappropriate context or a system-specific term in relation to the wrong legal system. Furthermore, they would also be made aware of the reasons why terminological evolution and variation are necessary, such as when a conceptual shift occurs in the legal field under examination or when a term acquires negative connotations and must therefore be replaced with a more neutral term. 

studying and practising. The opportunity to knowingly consider the diachronic dimension would prompt them to think critically about how legal language and legal terminology are used and how they evolve. By drawing the students' attention to the multilingual regime of the $\mathrm{EU}$, it would be possible to make them aware of the complexity of multilingual primary and secondary term creation on the one hand (Peruzzo 2012; Temmerman 2018), and of the linguistic impact of EU legislation on national legislation on the other. Indeed, this article provides evidence in support of the fact that legal terminology does not necessarily evolve at the same pace as the underlying concepts, but it should also be borne in mind that every EU official language evolves separately (Peruzzo 2017). The terminologisation process in EU legal texts thus has multiple facets that future lawyers should be aware of. Although foreseeing what law students will decide to do in the future is impossible, it is very likely that, given the intertwined legal order in which they operate, they will find themselves in a situation where reconstructing the legal and terminological evolution of certain legal notions is necessary. Suffice it to mention here cases where legal representation is needed in cross-border disputes, where comparative studies need to be carried out in cases brought before international courts of justice or when an EU legal act must be transposed into national legislation. In all these cases, highly refined linguistic skills which do not neglect the diachronic dimension would certainly prove useful.

developed linguistic skills are also at the core of legal translators' and legal terminologists' jobs. Understanding how legal notions and legal terminology evolve over time is fundamental for both professional profiles (that, in some cases, co-exist in the same individual). As regards legal translators, the diachronic dimension can determine the success of a translation. For instance, it would be inappropriate, or even unacceptable, to use an obsolete target-language term to translate a source-language term identifying a legal notion that has undergone a conceptual shift such as in the cases of formal neology illustrated above. However, in other cases the use of obsolete target-language terms is a conscious translation technique (De Groot 2000: 145; Scarpa et al. 2017: 79): the choice of an obsolete term is deliberate and is made to mark linguistically - the differences between the source and the target legal systems.

It goes without saying that the diachronic aspect is equally relevant for legal terminologists. Although the diachronic dimension has been long neglected in terminology, it is now gaining increasing interest, especially with reference to translation-oriented terminology. In order to cover all the information that a legal translator needs to make the most appropriate terminological choice in relation to his or her translation task, a terminological entry must also contain diachronic information. As seen above, a legal field and the terminology used in it can undergo considerable changes in a relatively short time span. If the time span is extended, the changes can be even more remarkable. Future legal terminologists (and future legal translators) should be exposed to diachronic evolution phenomena in legal terminology as early in their training as possible. This would allow them to develop their own strategies to describe these phenomena in terminological entries. These strategies could also turn into best practices for recording diachronic data in terminological resources that are not necessarily aimed at translators. For example, given that legal language is one of the tools of the trade of lawmakers, legal counsels, and lawyers in general, these professionals constitute a large potential group of end users of legal 
terminological resources. Therefore, in a targeted training in legal terminology and terminology management, the different needs of various groups of end users should be considered and the way diachronic information is provided should be modulated according to these needs.

\section{Conclusions}

In this article, a study was carried out on two EU legal acts adopted to increase the degree of harmonisation of victims' fundamental rights within the EU. The first legal act is Council Framework Decision 2001/220/JHA, which constitutes the first milestone in the development of an EU legal framework of victims' rights. It was modified and further reinforced by the adoption, in 2011, of the directives addressing victims of trafficking in human beings and child victims of sexual abuse, sexual exploitation, and child pornography, and, one year later, of Directive 2012/29/EU. The latter is precisely the second legal act considered in this study, since it provides for a wide spectrum of protection and safeguards granted to all victims of crime, which is similar to but more fine-grained than the one envisaged in the Framework Decision.

The study was conducted on the terms following the pattern "right + TYPE OF RIGHT" and found that, even in a short time span such as a decade, legal terminology evolves and does so in different ways. The study revealed two significant aspects: firstly, that a legal concept is not necessarily identified by a term, and, secondly, that terminologisation is a gradual process. As regards the first aspect, it can be said that, at the beginning of the new millennium, the EU felt the need to provide its Member States with a framework to safeguard certain victims' rights, but at the same time did not feel the need to identify those rights with a legal term containing the word "right." By comparing Council Framework Decision 2001/220/JHA with Directive 2012/29/EU, three types of shortperiod evolution phenomena were identified, namely complete neology, formal neology, and stability. The instances of complete neology and stability represent a minority in the study, while most of the terms extracted belong to formal neology. Indeed, the rights provided for in the former legal act underwent conceptual modifications that were accompanied by a terminologisation process and this process became evident in the latter legal act, where instances of formal neology were observed. To illustrate how the phenomenon of formal neology manifests itself in EU legal texts in more detail, the linguistic material used to refer to a certain type of right in the two acts was compared. By doing so, formal neology was further divided into three subcategories: i) new terms that replace existing terms, ii) terms that replace other expressions that cannot be considered terms (usually in the form of obligations for Member States), and iii) terms that are hyponyms of existing terms.

On the basis of the study of short-period evolution phenomena in legal terminology, the presence, absence, and modification of legal terms can be described as the life cycle of a living creature. In the final part of this article, it was argued that law, legal translation, and legal terminology students would benefit from the study of terminological evolution and variation. The exposure to such phenomena in a learning environment would allow students to raise their awareness of the multidimensionality of legal systems and legal terminologies. It would also allow them to understand how important it is to consider different factors, such as the number of legal systems and 
the time of reference involved, when making a terminological choice or recording terminological information in a database or a knowledge base.

\section{BIBLIOGRAPHY}

BAJČIĆ, Martina. 2010. “Challenges of translating EU terminology”. In GOTTI, M. \& C. WILLIAMS (eds.), Legal Discourse across Languages and Cultures. Bern: Peter Lang, 75-94.

BASSIOUNI, Cheriff M.. 2006. "International recognition of victims' rights”. Human Rights Law Review 6/2, 203-279.

BESTUÉ, Carmen. 2016. “Translating law in the digital age. Translation problems or matters of legal interpretation?”. Perspectives: Studies in Translatology 24/4, 576-590.

BIEL, Łucja. 2008. "Legal terminology in translation practice: dictionaries, googling or discussion forums?”. SKASE Journal of Translation and Interpretation 3/1, 22-38.

CAO, Deborah. 2007. Translating Law. Clevedon/Buffalo/Toronto: Multilingual Matters. DE BESSÉ, Bruno. 2000. “Le domaine.” In BÉJOINT, H. \& P. THOIRON, Le sens en terminologie, Travaux du CRTT (Centre de Recherche en Terminologie et Traduction). Lyon: Presses Universitaires, 182-197. DE GROOT, Gerard-René. 2000. "La traduzione di informazioni giuridiche”. Ars Interpretandi. Traduzione e Diritto, 135-154.

FISCHER, Márta. 2010. “Language (policy), translation and terminology in the European Union”. In THELEN, M. \& F. STEURS, Terminology in Everyday Life. Amsterdam/Philadelphia: John Benjamins, 2133.

FREIXA, Judit. 2006. "Causes of denominative variation in terminology. A typology proposal". Terminology 12/1, 51-77.

GRoenhuiJSEN, Mark S. \& Antony Pemberton. 2009. "The EU framework decision for victims of crime: does hard law make a difference?". European Journal of Crime, Criminal Law and Criminal Justice 17/1, 43-59.

IORIATTI FERRARI, Elena. 2014. "Found in translation: National concepts and EU legal terminology". In PASA, B. \& L. MORRA, Translating the DCFR and Drafting the CESL: A pragmatic perspective. Munich: Sellier European Law Publishers, 233-245.

LEMMENS, Koen. 2011. “The slow dynamics of legal language: Festina lente?” Terminology 17/1, 7493.

LUPÁRIA, Luca (ed.). 2015. Victims and Criminal Justice: European standards and national good practices. Padua: Wolters Kluwer.

LUPÁRIA, LUCa \& JaCopo DELLA TORRE. (forthcoming). "Victims of crime in the area of freedom, security and justice”. In IGLESIAS, S. \& M. GONZÁLEZ, Fundamental Rights in the EU Area of Freedom, Security and Justice. Cambridge: Cambridge University Press. 
MORGAN, A. M. 1987. “Victim rights: Criminal law: Remembering the 'Forgotten Person' in the criminal justice system”. Marquette Law Review 70/3, 572-597.

PERUZZO, Katia. 2012. "Secondary term formation within the EU: term transfer, legal transplant or approximation of Member States' legal systems?". JoSTrans - The Journal of Specialised Translation 18 (Special issue “Terminology, Phraseology and Translation"), 175-186.

PERUZzo, Katia. 2013. "Short-period evolution in EU legal texts: old and new terms, old and new concepts". Linguistica 53/2,39-53.

PERUZZO, Katia. 2017. "Legal system: an additional variable in the analysis of short-term diachronic evolution of legal terminology". International Journal of Legal Discourse 2/2, 291-313. PICTON, Aurélie. 2011. "Picturing short-period diachronic phenomena in specialised corpora: A textual terminology description of the dynamics of knowledge in space technologies. Terminology 17/1, 134-156.

PICTON, Aurélie. 2014. "The dynamics of terminology in short-term diachrony. A proposal for a corpus-based methodology to observe knowledge evolution". In TEMMERMAN, R. \& M. VAN CAMPENHOUDT, Dynamics and Terminology. An interdisciplinary perspective on monolingual and multilingual culture-bound communication. Amsterdam/Philadelphia: John Benjamins, 157-182. PRIETO RAMOS, Fernando. 2014. "Parameters for problem-solving in legal translation: Implications for legal lexicography and institutional terminology management”. In CHENG, L., K. K. SIN \& A. WAGNER, The Ashgate Handbook of Legal Translation. Farnham: Ashgate Publishing Limited, 121-134. SAGER, Juan C. 1990. A Practical Course in Terminology Processing. Amsterdam/Philadelphia: John Benjamins.

SANDRINI, Peter. 1996. "Comparative analysis of legal terms: Equivalence revisited". In GALINSKI, C. \& K. D. sCHMITZ, TKE '96: Terminology and Knowledge Engineering. Frankfurt: Indeks Verlag, 342-351.

SCARPA, Federica, Katia PERUZzo \& Gianluca PONTRANDOLFO. 2017. "Methodological, terminological and phraseological challenges in the translation into English of the Italian Code of Criminal Procedure: What's new in the second edition". In GIALUZ, M., L. LUPÁRIA \& F. SCARPA, The Italian Code of Criminal Procedure. Critical Essays and English Translation, 2nd edition. Milan: Wolters Kluwer/ CEDAM, 57-95.

TEMMERMAN, Rita. 2018. "European Union multilingual primary term creation and the impact of its neologisms on national adaptations". Parallèles 30/1, 8-20.

\section{Legislation}

Council Directive 2004/80/EC of 29 April 2004 relating to compensation to crime victims, OJ L $261 / 15$.

Council Framework Decision of 15 March 2001 on the standing of victims in criminal proceedings (2001/220/JHA), OJ L 82/1.

Directive 2011/36/EU on preventing and combating trafficking in human beings and protecting its victims, and replacing Council Framework Decision 2002/629/JHA, OJ L 88/6.

Directive 2011/93/EU on combating the sexual abuse and sexual exploitation of children and child pornography, and replacing Council Framework Decision 2004/68/JHA, OJ L 335/1.

Directive 2012/29/EU of the European Parliament and of the Council of 25 October 2012 establishing minimum standards on the rights, support and protection of victims of crime, and replacing Council Framework Decision 2001/220/JHA, OJ L 315/57. 
Directive 2017/541/EU on combating terrorism and replacing Council Framework Decision 2002/475/JHA and amending Council Decision 2005/671/JHA, OJ L 88/6.

\section{ABSTRACTS}

Council Framework Decision 2001/220/JHA was the first legal act adopted by the European Union to lay down general provisions addressing victims of crime and their rights. Significant progress was achieved a decade later by adopting Directive 2012/29/EU, which established minimum standards on the rights, support, and protection of victims of crime. This article presents a study conducted on the terms starting with the head element "right" extracted from both acts. The aim was to determine whether the legal progress experienced in a decade was accompanied by an evolution in the terminology used. The study revealed that, when legal terminology is analysed from a diachronic perspective, different phenomena can be observed: in this case, instances of stability, formal neology, and complete neology were identified. Diachronic evolution phenomena in legal terminology are then considered from a didactic perspective: students of law, legal translation, and legal terminology are deemed likely to benefit significantly from the inclusion of the diachronic dimension in their studies.

La décision-cadre 2001/220/JAI du Conseil a été le premier acte juridique adopté par l'Union européenne à énoncer des dispositions générales concernant les victimes de la criminalité et leurs droits. Dix ans plus tard, des progrès significatifs ont été accomplis grâce à l'adoption de la directive 2012/29/UE, qui a établi des normes minimales concernant les droits, le soutien et la protection des victimes de la criminalité. Cet article présente une étude menée sur les termes commençant par l'élément de tête « right » extraits des deux actes susmentionnés. L'objectif était de déterminer si les progrès juridiques réalisés au cours d'une décennie se sont accompagnés d'une évolution de la terminologie utilisée. L'étude a révélé que, lorsque la terminologie juridique est analysée dans une perspective diachronique, différents phénomènes peuvent être observés, à savoir des cas de stabilité, de néologie formelle et de néologie totale. Les phénomènes d'évolution diachronique dans la terminologie juridique sont ensuite considérés d'un point de vue didactique pour examiner les bénéfices potentiels que les étudiants en droit, en traduction juridique et en terminologie juridique pourraient tirer de l'introduction de la dimension diachronique.

\section{INDEX}

Mots-clés: diachronie, formation terminologique primaire, néologie, terminologie juridique, terminologisation

Keywords: diachrony, legal terminology, neology, primary term creation, terminologisation

\section{AUTHOR}

\section{KATIA PERUZZO}

Katia Peruzzo holds a PhD in Interpreting and Translation Studies from the University of Trieste. She is a research fellow in English Language and Translation at the Department of Linguistics and Comparative Cultural Studies of the Ca' Foscari University of Venice. Her research interests are legal English, legal terminology and translation, terminological variation, knowledge representation, and multidimensionality. katia.peruzzo@unive.it 